\title{
PEMAHAMAN TERHADAP TANGGUNGJAWAB, HAK DAN KEWAJIBAN PEGAWAI TERHADAP U.U. NO 5 TAHUN 2014 TENTANG APARATUR SIPIL NEGARA
}

\author{
Muzayanah \\ Fakultas Hukum, Universitas Stikubak (UNISBANK) Semarang \\ E-mail :muzayanah@edu.unisbanl.ac.id
}

\begin{abstract}
Abstrak
Aparatur Sipil Negara yang kita kenal dengan sebutan ASN merupakan Ujung tombak Pemerintahan terhadap masyarakat yang bertujuan melaksanakan tugas pemerintahan baik yang ada di pusat maupun di daerah seluruh wilayah Negara Republik Indonesia. Sebagai penyelenggara pemerintahan, ASN bertanggungjawab secara menyeluruh untuk memenuhi kebutuhan kehidupan dalam bermasyarakat. Guna mencapai tujuan nasional bangsa Indonesia tersebut diperlukan ASN yang professional, bebas dari intervensi politik, bersih dari praktik korupsi, kolusi dan nepotisme sehingga mampu untuk menyelenggarakan pelayanan publik bagi masyarakat serta mampu untuk melaksanakan peran sebagai perekat persatuan dan kesatuan bangsa berdasarkan Pancasila dan UUD Negara Republik Indonesia Tahun 1945. Penelitian ini merupakan penelitian yuridis normatif dengan spesifikasi penelitan kepustakaan (Library Reasearch) yang bertujuan untuk menjelaskan tentang pemahaman terhadap tanggungjawab, Hak dan Kewajiban ASN pada kewajiban dalam melaksanakan pekerjaan yang menjadi tanggungjawabnya yang sesuai dengan peraturan perundangan yang telah ditentukan. Pemahaman ASN terhadap Tanggungjawab, Hak dan Kewajiban ASN sebagaimana yang telah diatur dalam Undang-undang Nomor 5 Tahun 2014 tentang ASN merupakan upaya dalam mewujudkan ASN yang profesional dalam menjalankan fungsi serta tugasnya untuk menyelenggarakan pemerintahan yang berwibawa dan bertanggungjawab kepada seluruh rakyat Indonesia yang telah digariskan oleh Pendiri negara (The Founding Fathers) Republik Indonesia. Hasil penelitian ini mendiskripsikan bahwa ASN merupakan Pelaksana penyelanggara Pemerintahan Negara Republik Indonesia yang bekerja secara Professional berdasarkan system merit (cakap dan ahli) di bidang masing-masing. Setiap ASN mampu untuk memahami tanggungjawab, Hak dan Kewajiban bagi dirinya dan berupaya untuk melaksanakannya. ASN memahami tanggungjawab, hak dan kewajiban berdasarkan ketentuan UU no. 5 Tahun 2014 tentang Aparatur Sipil Negara membuktikan bahwa melaui ASN inilah Pemerintah telah berupaya untuk mewujudkan tujuan Nasional bangsa Indonesia melalui ASN yang bekerja dan melakukan kewajiban dalam melaksanakan tugas dan tangungjawab kepada seluruh rakyat.
\end{abstract}

Kata Kunci: Pemahaman ASN, tanggungjawab hak dan kewajiban. 


\begin{abstract}
The State Civil Apparatus, which we know as the ASN, is the spearhead of government for the people who aim to carry out governmental tasks both at the center and in the entire territory of the Republic of Indonesia. As a government organizer, ASN is overall responsible for meeting the needs of life in society. In order to achieve the national goals of the Indonesian nation, a professional ASN is required, free from political intervention, clean of corrupt practices, collusion and nepotism so that it is able to provide public services to the community and be able to carry out its role as the glue of national unity and integrity based on the Pancasila and the Republic of the Republic of Indonesia Indonesia in 1945. This research is a normative juridical study with a library research specification (Library Reasearch) which aims to explain the understanding of the responsibilities, rights and obligations of ASN on the obligations in carrying out work which is its responsibility in accordance with the specified laws and regulations. ASN's understanding of ASN's responsibilities, rights and obligations as stipulated in Law Number 5 of 2014 concerning ASN is an effort to realize ASN that is professional in carrying out its functions and duties to carry out an authoritative and responsible government to all Indonesians outlined by The Founding Fathers of the Republic of Indonesia. The results of this study describe that ASN is the organizer of the Government of the Republic of Indonesia who works Professionally based on a merit system (competent and expert) in their respective fields. Every ASN is able to understand its responsibilities, rights and obligations and work to implement it. ASN understands its responsibilities, rights and obligations based on the provisions of Law no. 5 of 2014 concerning the State Civil Apparatus proves that through this ASN the Government has sought to realize the National goals of the Indonesian people through ASN who work and perform obligations in carrying out their duties and responsibilities to all the people.
\end{abstract}

Keywords: Understanding ASN, responsibility rights and obligations

\section{Pendahuluan}

Negara Republik Indonesia sebagai negara yang merdeka, mampu untuk menyelenggarakan pemerintahan negara dengan bebas merdeka tanpa adanya tekanan sebagaimana bagi negara yang dijajah sebelumnya. Alinea pembukaan UUD 1945 menyebutkan : "Kemudian dari pada itu untuk membentuk suatu Pemerintah Negara Indonesia yang melindungi segenap bangsa Indonesia dan seluruh tumpah darah Indonesia, dan untuk memajukan kesejahteraan umum, mencerdaskan kehidupan bangsa, dan ikut melaksanakan ketertiban dunia yang berdasarkan kemerdekaan, perdamaian abadi dan keadilan sosial, maka disusunlah kemerdekaan kebangsaan Indonesia itu dalam suatu Undang-Undang Dasar Negara Indonesia, yang terbentuk dalam suatu susunan Negara Republik Indonesia yang berkedaulatan rakyat dengan berdasar kepada : Ketuhanan Yang Maha Esa, Kemanusiaan Yang Adil dan beradab, Persatuan Indonesia, dan Kerakyatan Yang dipimpin oleh Hikmat kebijaksanaan dalam Permusyawaratan/Perwakilan 
serta dengan mewujudkan Keadilan Sosial bagi seluruh rakyat Indonesia".

Negara Republik Indonesia memiliki tujuan nasional yang hendak dicapai dalam rangka mencapai keadilan sosial bagi seluruh rakyat Indonesia. Keadilan yang dimaksud merupakan wujud kesejahteraan sosial bagi seluruh rakyat Indonesia. Untuk mencapai tujuan tersebut, diperlukan penyelenggara negara yang mampu melaksanakan tugas negara sehingga mampu mencapai tujuan yang dimaksud. Sangat dibutuhkan penyelenggara negara yang mampu melaksanakan tugas dan tanggungjawab penuh pengabdian, maka penyelenggaraan negara akan dilaksanakan untuk seluruh wilayah negara Indonesia. Dengan demikian Aparatur Sipil Negara perlu di kelola dengan menetapkan kebijakan manajemen ASN. Dalam upaya untuk menetapkan kebijakan Manajemen ASN, telah dibentuk Komisi Aparatur Sipil Negara (KASN) yang mandiri dan bebas dari intervensi politik. Terutama dalam rangka Indonesia memilih kepemimpinan Negara yang telah dilaksanakan Pemilihan Umum Presiden yang diselenggarakan pada tahun 2019 . Maksud dibentuknya KASN ini adalah dalam rangka untuk memonitoring dan mengevaluasi hal tersebut. UU tentang ASN ini menentukan tentang Tanggungjawab, Hak dan Kewajiban pegawai Aparatur Sipil Negara (ASN) untuk melaksanakan tugas sebagai penyelenggara Negara dan pemerintahan yang sadar akan tangunggjawab untuk mewujudkan tujuan Nasional bangsa Indonesia sebagaimana tercantum dalam alinea ke-4 Pembukaan Undang- Undang Dasar Negara Republik Indonesia Tahun 1945.Perlu pemahaman terhadap tanggungjawab, hak dan kewajiban bagi setiap ASN untuk mengetahui serta melaksanakan tugas dengan sebaik-baiknya penyelenggaraan pemerintahan berjalan dengan baik dan sesuai dengan ketentuan peraturan perundang-undangan yang berlaku sebagaimana diatur dalam U.U.Nomor 5 tahun 2014 tentang Aparatur Sipil Negara.

\section{Permasalahan}

Bagaimanakah Pemahaman Terhadap Tanggungjawab, Hak dan Kewajiban pegawai pemerintah terhadap Undang-Undang Nomor 5 tahun 2014 Tentang Aparatur Sipil Negara?

\section{Metode Pendekatan}

Penelitian ini menggunakan metode pendekatan yang Yuridis Normatif.

Adapun Peraturan-peraturan tertulis yang dimaksud adalah Ketentuan Perundang-undangan yang menjadi landasan berpijak dalam menjawab permasalahan yang ada. Sedangkan pendekatan normative merupakan suatu pendekatan yang bertujuan untuk memperjelas keadaan dengan melihat peraturan perundangundangan dan ketentuan hukum, juga menelaah kenyataan dalam praktek di masyarakat.

\begin{tabular}{lr}
\hline Terutama pada & peneltian \\
ini yang menjelaskan tentang \\
Apakah pegawai ASN memahami
\end{tabular}


akan tanggungjawab, Hak dan Kewajibannya sebagaimana yang telah diatur dalam Undang-Undang Nomor 5 tahun 2014 tentang Aparatur Sipil Negara?

\section{Spesifikasi Penelitian}

Spesifikasi dalam penelitian ini adalah deskriptif analitis, yaitu penelitian yang bertujuan untuk mendiskripsikan mengenai Pemahaman Pegawai ASN terhadap tanggunjawab, Hak dan Kewajibannya terhadap Undang - Undang Nomor 5 Tahun 2014 tentang Aparatur Sipil Negara. Perbaikan terhadap kinerja pegawai ASN dapat dilihat dan diamati tatkala Pegawai ASN memahami tanggungjawab, Hak dan Kewajiban pegawai ASN dan mampu melaksanakan tugas yang menjadi tanggungjawabnya serta mengerti serta memahami apa saja yang menjadi hak-hak pegawai ASN dan apa pula yang menjadi kewajiban- kewajiban Pegawai ASN.

Pelayanan publik yang baik serta tanggungjawab atas pekerjaan bagi setiap pegawai ASN akan mampu untuk mewujudkan penyelenggaraan pemerintahan negara yang baik. Melaksanakn tugas dengan sebaikbaiknya oleh Aparatur Sipil Negara merupakan bentuk pertanggungjawaban terhadap pelayanan terhadap masyarakat yang membutuhkan penyelesaian akan masalah yang dihadapi dalam memenuhi kebutuhan hidup masyarakat. Perolehan hak-hak bagi Aparatur ASipil Negara akan mendorong untuk melaksanakan pekerjaan dan tanggungjawabnya dengan baik. Oleh sebab itu pemenuhan hak-hak pegawai merupakan motivasi untuk melaksanakan pekerjaan dan tanggungjawabnya secara maksimal.Kesadaran terhadap tanggungjawab atas kinerja yang harus diwujudkan akan mampu merealisasikan hak-hak dan kewajiban sebagai Aparatur Sipil Negara yang memiliki kompetensi.

\section{Sumber Data}

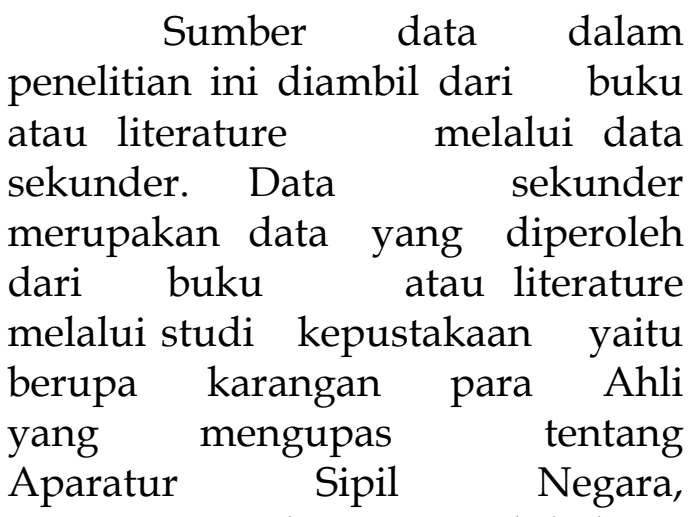
Tanggungjawab, Hak-haknya serta kewajibannya yang berkaitan dengan penyelenggaraan Pemerintahan Negara Republik Indonesia, dan campuran dari bahan- bahan lain seperti Jurnal, majalah hukum maupun tulisan tulisan karya ilmiah yang membahas mengenai hal-ikhwal dalam membahas serta menjelaskan tentang Pegawai ASN, tanggungjawab serta hak dan kewajiban-kewajibannya.dalam rangka untuk mendapatkan pengetahuan teoritis di dalam penyusunan laporan penelitian ini.Data sekunder dapat dikategorikan dalam 2(dua) kelompok Yaitu:

1. Data pendukung yang bersifat pribadi, contohnya adalah dokumen 


\author{
Privat atau data personal \\ yang \\ disimpan dimana seorang \\ bekerja \\ atau pernah bekerja.
}

2. Data pendukung yang bersifat publik, contohnya adalah data arsip, data resmi dari instansi pemerintah atau data lain yang dipublikasikan.

Sumber materi pendukung adalah data yang diperoleh dari studi pustaka. Dengan studi pustaka ini, peneliti mampu untuk mempelajari dokumen yaitu dengan melakukan analisa isi(content analysys).

Dalam penelitian ini sumber data dikelompokkan menjadi 3(tiga) yaitu:

1. Peraturan dasar utama, yaitu

a. U.U. D 1945

b. U.U. No:5 Tahun 2014

c. U.U. Nomor 8 tahun 1974

d. U.U. Nomor 43 tahun

1999 tentang Perubahan atas Undang-Undang Nomor 8 Tahun 1974

2 Bahan Hukum sekunder, yaitu bahan yang memberi penjelasan bagi

Hukum primer, terdiri dari: Buku Bacaan yang berupa:

a Pustaka

b Majalah-majalah dan dokumen-dokumen yang berkaitan dengan Aparatur Sipil Negara (ASN).

3. Bahan Hukum Tersier, yaitu bahan

hukum yang memberikan petunjuk dan Penjelasan terhadap bahan hukum primer dan sekunder, yang terdiri dari Bibliografi (daftar bacaan atau artikel). Selain itu untuk melengkapi dan menjelaskan data sekunder tersebut, Penelitian ini Juga dilengkapi dengan hasil wawancara dilakukan untuk melengkapi data guna pengumpulan data melalui wawancara dengan responden.

\section{Pengumpulan Data}

Dalam pengumpulan data yang digunakan oleh Peneliti melalui studi Kepustakaan (Library Research) serta ditunjang dengan wawancara.

Data yang diperoleh dari kepustakaan dilakukan dengan cara menelaah bahan hukum primer, sekunder dan tersier, yang membahas tentang apakah Pemahaman Pegawai ASN terhadap tangunggjawab, hak dan kewajibannya terhadap Undangundang Nomor 5 tahun 2014 yang mengatur tentang Aparatur Sipil Negara.

melakukan teknik itu Peneliti dengan responden berstatus sebagai pegawai ASN yang menjelaskan tentang apa yang diketahuinya tentang tanggung jawab, Hak dan kewajibannya sebagai pegawai ASN.

Teknik wawancara dilakukan dengan menanyakan hallihkwal yang berkaitan dengan pekerjaan pegawai pemerintah yang telah dilaksanakan maupun yang akan dilaksanakan sebagai rasa tanggungjawab atas pekerjaan dan 
pengabdiannya kepada Negara. Peneliti menanyakan secara rinci dan responden menjawab dengan bebas berdasarkan catatan pertanyaan dengan mengajukan daftar pertanyaaan yang telah disiapkan terlebih dahulu yang berupa baik pertanyaan terbuka maupun tertutup oleh peneliti untuk dapat dipahami dan dijawab oleh Responden. Segala sesuatu secara bebas ditanyakan kepada responden dengan maksud untuk menggali informasi sebanyakbanyaknya agar diperoleh masukan yang obyektif dan yang terjadi sesungguhnya tentang pemahaman ASN terhadap peraturan yang mengatur serta tata ketja yang tertib untuk dilaksanakan dengan sebaikbaiknya dalam menyelenggarakan pemerintahan.

Dalam pertanyaan terbuka, maka responden memiliki kebebasan untuk menjawab pertanyaan yang diajukan dan memberikan pendapat tentang seluk-beluk serta apa saja yang ingin disampaikan berkaitan dengan tanggungjawab, hak dan kewajiban yang diketahuinya dan dilaksanaknnya sebagai pegawai atau Aparatur Sipil Negara.

Sedangkan

pertanyaan tertutup dapat dijawab dengan jawaban yang telah disediakan oleh Peneliti yang berkaitan dengan tanggungjawab, hak dan kewajiban sebagai penyelenggaran negara dan menjadi Aparatur Sipil Negara.Jawaban telah tersedia, maka responden hanya tinggal memilih jawabannya saja.

\section{Metode Analisa Data}

Setelah peneliti mendapatkan banyak informasi tentang peleksanaan pekerjaan yang berkaitan dengan pemahaman tanggungjawab, hak dan kewajiban penyelenggara pemerintahan, maka dapat diolah dengan menyajikan hasil penelitian. Penyusunan laporan penelitian ini Adalah menggambarkan keadaan tentang ASN yang menjalankan tugas pemerintahan dengan telah memahami ketentuan peraturan perundangan yang berlaku. Hal ini merupakan gambaran atau deskriptif analitis. Pada laporam penelitian ini tidak menampilkan data statistik, namun mendiskripsikan analisis data yang telah diolah. Yaitu dengan cara mengambil simpulan yang dimulai dari hal-hal yang bersifat umum menuju hal-hal yang bersifat khusus. Analisis ini merupakan suatu metode analisis yang dilakukan dengan cara mengumpulkan semua bahan atau data yang diperoleh untuk kemudian ditelaah dan dianalisa berdasarkan peraturan perundang-undangan dan teori yang berkaitan dengan permasalahan yang dibahas. Selanjutnya mengambil kesimpulan dengan menggunakan metode deduktif yaitu proses penarikan simpulan yang dimulai dari hal- hal yang bersifat umum menuju hal hal yang bersifat khusus, yang terkait dengan pemahaman pegawai ASN terhadap tanggungjawab, hak dan kewajibannya terhadap Undang-Undang 
tentang Aparatur Sipil Negara (ASN).

\section{Pembahasan}

Pemahaman Pegawai ASN Terhadap Tanggungjawab Pegawai ASN

\section{Akuntabilitas}

Setiap pegawai pemerintah memiliki tanggungjawab, hak serta kewajiban penuh yang harus dilakukan untuk menyelenggaran pemerintahan Negara. Untuk menyelenggarakan pemerintahan Negara baik yang ada di pusat maupun yang ada di daerah besar dan kecil di seluruh wilayah Negara Republik Indonesia, dari Sabang sampai pulau Rote, maka setiap pegawai Pemerintah berkewajiban dan bertanggungjawab untuk melaksanakan tugas pemerintahan dengan sebaik-baiknya. oleh sebab itu maka setiap Pegawai ASN memiliki kewajiban untuk mengutamakan kepentingan masyarakat di atas kepentingan pribadi maupun kelompok. Sangat diutamakan kepentingan masyarakat dengan tujuan untuk menjawab permasalahan yang dihadapi oleh masyarakat. Dengan menjawab dan menyelesaiakn masalah yang dihadapi oleh masyarakat, tentunya hal ini akan mewijudkan harapan masyarakat untuk hidup lebih baik.

Setiap pegawai pemerintah dalam hal ini yang disebut dengan ASN memiliki kewajiban dan tanggungjawab sebagai berikut:

- Mengutamakan kepentingan Umum yang harus dilayani guna terpenuhinya kebutuhan dasar dan kebutuhan dalam melaksanakan kehidupannya sehari-hari dalam menyelenggarakan

kegiatannya. Mampu mengutamakan kepentingan masyarakat lebih dari kepentingan golongan maupun pribadi, Oleh sebab itu maka setiap ASN memiliki kewajiban untuk mengutamakan kepentingan masyarakat di atas kepentingan pribadi maupun kelompoknya.

- Memiliki pemahaman dan kesadaran untuk menghindar dan mencegah keterlibatan ASN dalam politik praktis Artinya bahwa setiap pegawai ASN harus memiliki pemahaman akan dirinya yang tidak terlibat dalam kegiatan politik praktis dan mampu menjaga netralitas Pegawai ASN dari pengaruh dan keterlibatannya dalam kegiatan politik praktis. Setiap ASN tidak dibenarkan untuk terlibat dalam politik praktis yang memihak golongan tertentu. Oleh sebab itu maka setiap ASN adalah bekerja untuk kepentingan semua orang, semua masyarakat, tidak terkecuali. Bahwa setiap ASN wajib membantu, melayani dan bekerja untuk kepentingan rakyat. Setiap ASN harus mampu menjaga netralitas diri agar tidak terjebak dalam membela dan mendukung kelompokkelompok tertentu, sehingga tidak netral dan memihak. Sikap netral dan tidak 
memihak ini akan menjadikan setiap ASN akan mampu berbuat dan bekerja untuk semua orang dan semua masyarakat dan tidak memilih-milih mana masyarakat yang akan dilayani. Berarti semua masyarakat akan mendapat perlakuan dan pelayanan yang sama oleh ASN dalam melaksanakan pekerjaannya.

- Memperlakukan warga negara secara sama dan adil dalam penyelenggaraan pemerintahan dan pelayanan publik; artinya bahwa setiap pegawai ASN memiliki kewajiban untuk memberikan pelayanan yang terbaik bagi masyarakat dalam pelaksanaan penyelenggaraan

pemerintahan negara. Tidak memilih-milih orang untuk melayani masyarakat. Sehingga semua akan dilayani bersama dan adil dalam bekerja.

- Melakukan pelayanan yang dibutuhkan oleh setiap orang yang datang untuk mengajukan keperluan yang harus diselesaikan dalam memenuhi kebutuhannya untuk kehidupannya. Artinya Bahwa sebagai pegawai ASN harus memiliki sikap, perilaku yang terhormat serta mampu melaksanakan pemerintahan yang bertanggungjawab kepada masyarakat. Setiap ASN harus menjaga kehormatannya dengan sebaik-baiknya. Bekerja dengan jujur dan berintegritas, sehingga membawa diri dengan baik dan berwibawa. Setiap ASN harus memiliki sikap jujur dan berwibawa. Karena jujur akan membawa kepada tanggunjawab yang benar. Kejujuran dan kedisiplinan membawa ASN akan mampu bekerja dengan baik, sehingga masyarakat akan percaya akan kredibilitasnya. Kejujuran akan menjadikan ASN berada pada kepercayaan masyarakat yang sangat dibanggakan. Tidak ada perlakuan yang negative terhadap ASN, sehingga masyarakat yakin akan tercapainya harapan yang akan dicapainya.

Masyarakat menghendaki ASN tidak berbuat korupsi, Kolusi dan Nepotisme sehingga mampu bekerja dengan baik dan benar.

Sesungguhnya masalah akuntabilitas berbeda dengan responsibilitas atas tanggungjawab. Adapun yang dimaksud dengan responsibilitas adalah kewajiban untukbertanggungjawab.

Sedangkan Akuntabilitas adalah kewajiban pertanggungjawaban yang harus dicapai. Ada beberapa aspek dalam akuntabilitas, yaitu akuntabilitas adalah sebuah hubungan, akuntabilitas berorientasi pada hasil, akuntabilitas membutuhkan adanya laporan, akuntabilitas memerlukan konsekuensi, dan aknutabilitas memperbaiki kinerja. Menurut Bovens(2007) dalam bukunya Bambang Rudito (2016) 
$\begin{array}{lrr}\text { menyebutkan tentang } & \text { adanya } \\ \text { akuntabilitas } & \text { memiliki } 3 & \text { (tiga) }\end{array}$ fungsi Utama, yaitu:

- Untuk memiliki sikap netral sehingga mampu menjadi media yang baik dalam menjalin komunikasi dengan rajyat.(peran demokrasi).

- Untuk mampu menjadi tauladan sehingga mencegah terjadinya perbuatan yang tidak adil terhadap pekerjaannya berdasarkan Konstitusi (peran Konstitusional).

- Untuk meningkatkan sumber daya manusia dengan meningkatkan kemampuan serta kompetensi yang dimiliki oleh setiap pegawai pemerintah. efisiensi dan efektifitas (peran belajar)

\section{Pemahaman Terhadap Hak-hak Pegawai ASN}

Hak -hak Pegawai ASN sebagai berikut: Hak PNS di dalam UU no 5 tahun 2014 Pasal 21 diatur tentang ASN berhak memperoleh:

a. gaji, tunjangan, dan fasilitas;

b. cuti;

c. jaminan pensiun dan jaminan hari tua;

d. perlindungan; dan

e. pengembangan kompetensi.

Pegawai ASN memiliki tanggungjawab dalam Pasal 23 UU no 5 tahun 2014 yaitu:

Kewajiban Pegawai Pemerintah (ASN):

- Menjunjung tinggi Ideologi Pancasila merupakan kewajiban yang mendasar bagi setiap ASN, karena Pancasila merupakan
Ideologi bangsa dan negara Republik Indonesia. Pancasila merupakan falsafah bangsa Indonesia sehingga terdapat filosofi bangsa Indonesia tercantum dalam sila-sila Pancasila yang dimulai dari Sila Ketuhanan Yang Maha Esa, sila kemanusiaan Yang Adil dan Beradab; Sila Persatuan Indonesia; sila Kerakyatan Yang dipimpin oleh Hikmat Kebijaksanaan dalam Permusyawaratan /Perwakilan serta sila Keadilan Sosial bagi seluruh Rakyat Indonesia. Setiap ASN wajib menjunjung tinggi Falsafah Negara dan Ideologi Negara Pancasila. Setiap ASN wajib melaksanakn nilai-nilai Pancasila dengan benar. Oleh sebab itu setiap nilai-nilai Pancasila harus tertanam dalam hati setiap Aparatur Sipil Negara. Bahwa setiap ASN harus mampu menjalankan agama dengan benar dan sesuai dengan keyakinan dan kepercayaannya. Setiap ASN harus memiliki dan menanamkan nilai-nilai Kemanusiaan yang Adil dan Beradab, artinya bahwa setiap ASN harus mempu menjalin hubungan kemanusiaan yang Adil dan berbudaya. Hormatmenghormati dan bekerjasama dengan baik untuk mewujudkan nilainilai Persatuan Indonesia. Melaksnakan nilai-nilai 
kerakyatan yang dipimpin oleh hikmat kebijaksanaan dalam

permusyawaratan/perwakila $\mathrm{n}$, artinya bahwa setiap ASN harus memiliki kemampuan untuk melaksanakan kedaulatan rakyat melalui pemilihan Umum untuk menyampaikan aspirasinya.

- Setiap Pegawai Pemerintah wajib melaksanakan ketentuan UUD 1945 yang merupakan landasan hukum dan konstitusional Negara Republik Indonesia. UUD 1945 adalah landasan konstitusional Negara Republik Indonesia. Gambaran Negara Republik Indonesia terdapat dalam isi dari Konstitusi Negara Republik Indonesia. Konstitusi tertulis Negara Republik Indonesia dijelaskan dlam Pasal -pasal yang terdapat dalam UUD 1945. Dengan demikian bagi setiap Pegawai pemerintah dalam hal ini ASN wajib memahami dan melaksanakan ketentuan pasal-pasal yang ada didalamnya. Siapapun ASN wajib memahami dan melaksanakan ketentuan UUD Negara Republik Indonesia, karena dengan memahami ketentuan yang ada dalam konstitusi tertulis Negara Republik Indonesia ini ASN akan mampu menyelenggarakan pemerintahan dengan baik dan benar.
- Setiap Pegawai Pemerintah Wajib Taat kepada Pemerintah Negara Republik Indonesia dalam NKRI. Pemerintah Negara Kesatuan Republik Indonesia adalah Pemerintah Negara yang berdaulat, memiliki kedaulatan penuh dan utuh dalam menyelenggarakan pemerintahan Negara. Hal ini menjadi pusat pelaksana pemerintahan yang menyeluruh bagi suatu Negara Yaitu Negara Kesatua Republik Indonesia. Kewenangan yang dimiliki dengan kedaulatan penuh oleh Pemerintah Negara Republik Indonesia menjadi pedoman bagi setiap pegawai Pemerintah dalam hal ini ASN wajib menjalankan pemerintahan dengan baik. Taat, tunduk dan patuh terhadap Pemerintah Negara Republik Indonesia tidak boleh ditawar dan selalu harus siap untuk melaksanakannya. Oleh sebab itu penyelenggara Pemerintah di daerah adalah merupakan Perpanjangan tangan dari Pemerintah Pusat. Sehingga Pelaksana di daerah merupakan realisasi Pemerintahan Pusat yang ada.

Sehingga pekerjaan yang telah direncanakan oleh pemerintah pusat selalu harus ditindaklanjuti di setiap daerah agar tujuan dari pemerintah pusat dapat direalisasikan. 
- Menjaga keutuhan bangsa dan negara Indonesia agar tercipta suasana kondusif negara dan bangsa Indonesia agar tujuan nasional bangsa Indonesia dapat diwujudkan, menjunjung tinggi rasa kesatuan dan persatuan bangsa Indonesia, karena ASN merupakan alat pemersatu bangsa. Hal ini sesuai dengan sila ketiga Pancasila yaitu Persatuan Indonesia. Negara Republik Indonesia yang heterogen ini harus dijaga sebaik-baiknya agar perbedaan ini menjadi kebersamaan dalam hidup bermasyarakat, berbangsa dan bernegara. Bahwa berbeda suku, Ras dan agama serta adat-istiadat yang majemuk dan sangat banyak, mewajibkan ASN menjadi media atau alat pemersatu bangsa Indonesia. Menjaga nilai-nilai persatuan dan kesetuan Bangsa Indonesia, sehingga mampu untuk mewujudkan Negara Indonesia yang bersatu, berdaulat adil dan makmur.

- Kewajiban yang telah dilaksanakan oleh Pegawai ASN dalam menjaga persatuan dan kesatuan bangsa telah dilaksanakan dengan sebaik-baiknya. Membangun kebersamaan dalam menjalankan tugas sebagai pelayan masyarakat akan mampu menumbuhkan rasa saling menjaga dan memiliki keinginan untuk saling tolong -menolong dalam kebaikan dan kerjasama antar pegawai ASN. Hormat-menghormati, menjaga dan mambantu sesame, masyarakat menolong mewujudkan untuk kebersamaan dan persatuan untuk seluruh rakyat dan bangsa Indonesia. Hal ini yang menumbuhkan cinta tanah air.

- Bahwa setiap ASN mempunyai kewajiban untuk melaksanakan setiap Kebijakan yang telah dirumuskan dan dicanangkan untuk dilaksanakan.

Kebijakan pemerintah yang dicanangkan untuk dilaksanakan oleh setiap pegawai ASN dalam melaksanakan kegiatan pembangunan akan membawa dampak positif bagi masyarakat. Pegawai ASN yang melaksanakan tugas pembangunan sebagai pelaksana penyelenggara pemerintahan.Setiap

kebijakan pimpinan wajib dilaksanakan untuk menyelenggarakan negara. Karena dengan melaksanakan kebijakan pimpinan akan mewujudkan tujuan pembangunan yang direncanakan.

- Menaati ketentuan peraturan perundang-undangan;

Menjadi contoh dan teladan bagi masyarakat adalah 
kewajiban setiap ASN. Karena ASN sebagai penyelenggara Pemerintahan baik dari pusat sampai ke daerah, akan memberikan keteladanan bagi masyarakat secara keseluruhan. Pegawai ASN menaati peraturan perundang-undangan merupakan kewajiban karena untuk mewujudkan keteladanan setiap pegawai ASN dengan cara mematuhi peraturan perundangundangan akan mampu memberikan keteladanan bagi masyarakat.Setiap ASN wajib melaksanakan tugas dengan disiplin dalam bekerja.Taat azas, taat hukum serta mampu melaksanakan kewajiban.

- Melaksanakan tugas kedinasan dengan penuh pengabdian, kejujuran, kesadaran dan tanggungjawab;

Bahwa setiap ASN memiliki kewajiban untuk melaksanakan tugas kedinasan yang harus dilaksanakan dengan penuh pengabdian negara Bangsa dan Masyarakat. Kejujuran merupakan kunci utama dalam melaksanakan tugas negara. Setiap tugas kedinasan menjadi kewajiban bagi setiap ASN untuk melaksanakan dengan penuh tanggungjawab.Hal ini telah dilaksanakan dengan baik oleh pegawai ASN.

Hal ini tentu saja akan mampu menjaga kehormatan dan kewibawaan setiap pegawai ASN. Hal ini telah dilakukan oleh pegawai ASN agar mampu menunjukkan pelayanan dari pemerintah.

- Menyimpan rahasia jabatan dan hanya dapat mengemukakan rahasia jabatan sesuai dengan ketentuan peraturan perundang-undangan;

Hal ini menjadi kewajiban bagi setiap pegawai ASN untuk senantiasa bekerja dengan baik dan benar serta memiliki kepentingan untuk menjaga rahasia jabatan. Setiap pekerjaan selalu memiliki kerahasiaan dalam pekerjaan dan Jabatan yang ada didalamnya. Oleh sebab itu rahasia pekerjaan dan rahasia jabatan tidak boleh dibuka dan disebarluaskan untuk orang yang tidak berkepentingan atas rahasia jabatan dan rahasia pekerjaan tersebut. Menyimpan rahasia jabatan dan pekerjaan merupakan kewajiban setiap pegawai ASN dalam menjalankan jabatan dan pekerjaannya.

Dari hasil wawancara terhadap

Pegawai ASN yang diambil sebagai sampel yang dilakukan secara acak, pada dasarnya bahwa setiap pegawai ASN yang telah diwawancari oleh Peneliti menyatakan bahwa mereka telah memahami tentang tanggungjawab sebagai pegawai ASN dalam menjalankan tugasnya untuk 
melakukan pelayanan terhadap masyarakat dalam rangka untuk mewujudkan tujuan nasional bangsa Indonesia sebagaimana yang tercantum dalam UUD Negara Repubik Indonesia tahun 1945 khususnya yang tercantum dalam alinea ke-empat Pembukaan UUD 1945Demikian pula tentang Hak-hak yang dimiliki oleh Pegawai ASN pada dasarnya pegawai ASN memahami apa saja yang menjadi hak-hak nya sebagai pegawai ASN. Hasil wawancara yang peneliti lakukan terhadap beberapa pegawai ASN yang bekerja di salah satu sampel yaitu Kantor Kelurahan, dalam hal ini Kelurahan Kalicari, Kecamatan Pedurungan, Kota Semarang, telah memahami akan hak-hak nya sebagai pegawai ASN. Demikian juga ASN yang bekerja di Kantor Kelurahan Mlatiharjo, kecamatam Semarang Timur, Kota Semarang juga memahami akan tanggungjawab, hak dan kewajiban sebagai penyelenggaran pemerintahan. Oleh sabab itu dengan pemahaman akan tanggungjawab, hak-hak pegawai ASN ini akan menumbuhkan rasa percaya diri untuk tetap melayani masyarakat dengan sebaik-baiknya. Karena dengan memiliki hak-hak pegawai ASN ini akan dapat terpenuhinya kesejahteraan yang diharapkan bagi setiap pegawai ASN di seluruh wilyah negara Republik Indonesia. Pemahaman terhadap tanggungjawab, hak dan kewajiban pegawai ASN menumbuhkan semangat untuk mengabdi kepada masyarakat, bangsa dan negara Republik Indonesia.

Demikian juga terhadap
Pegawai ASN yang telah Peneliti wawancarai berkaitan dengan pemahaman Pegawai ASN terhadap tanggungjawab, hak dan kewajiban yang harus dimiliki dan dilaksanakan dengan sebaikbaiknya, maka pada sebagian besar reponden yang menyampaikan jawaban atas pertanyaan yang peneliti ajukan dan mereka menjawab bahwa mereka pada dasarnya memahami apa yang telah diatur dalam UU yang berlaku. Dengan telah memahami tanggungjawab, hak dan kewajiban pegawai ASN ini akan menjadikan mereka wajib melaksanakan tugas dan tangunggjawabnya terhadap penyelenggaraan negara serta melaksanakan pelayanan publik bagi seluruh masyarakat yang membutukan pelayanan yang baik oleh pemerintah dalam hal ini pegawai ASN.

\section{Kesimpulan}

1. Peraturan yang mengatur tentang Pegawai Pemerintah merupakan Peraturan Perundangundangan yang telah mereformasi birokrasi bagi Penyelanggaraan Aparatur Sipil negara. Pembentukan Aparatur Negara (ASN) yang memiliki integritas, professional, netral dan bebas dari hubungan politik, tidak melakukan korupsi, kolusi dan nepotisme, serta serta mampu menyelenggarakan pelayanan publik bagi masyarakat dan mampu berperan sebagai unsur perekat persatuan dan kesatuan bangsa berdasarkan Pancasila dan Undang-Undang Dasar Negara Republik Indonesia Tahun 1945. ASN telah menunjukkan pemahamannya terhadap peraturan 
Perundang-undangan yang berlaku. Dengan telah memahami ketentuan peraturan perundang-undangan yang berlaku, maka tanggungjawab hak dan kewajiban ASN sudah dimengerti dan dipahami. Apabila terjadi pelanggaran terhadap tanggungjawab, hak dan kewajiban ASN terhadap peraturan perundang-undangan yang berlaku, maka ASN memiliki konsekuensi logis untuk siap menerima sanksi tegas yang akan dijatuhkan kepadanya apabila terjadi pelanggaran.

Pelanggaran terhadap Tanggungjawab, Hak dan kewajiban ASN yang telah diatur dalam Perundang-undangan Yang berlaku, memiliki Konsekuensi logis dan sanksi yang dapat diterapkan kepada Pelanggarnya.

2. ASN merupakan profesi bagi PNS (Pegawai Negeri Sipil) dan PPPK (Pegawai Pemerintah dengan Perjanjian Kerja). ASN merupakan unsur utama dalam mewujudkan tujuan Nasional yang tercantum dalam Pembukaan UUD Negara Republik Indonesia Tahun 1945. Berdasarkan ketentuan pasal 3 dan 4 UU ASN yang mengatur tentang prinsip-prinsip dan nilai-nilai dasar yang harus dijunjung tinggi oleh ASN, maka dibuat suatu istilah sebutan ANEKA, yang merupakan akronim dari Akuntabilitas, Nasionalisme, Etika Publik, Komitmen mutu, Anti Korupsi. ANEKA yang diterapkan kepada ASN bertujuan untuk mewujudkan Aparatur Sipil Negara yang akuntabel dan berorientasi pada pelayanan publik serta selalu mengkedepankan kepentingan negara dan masyarakat.

3. ASN telah memahami apa yang menjadi tanggungjawab, Hak dan kewajiban yang telah diatur dalam ketentuan Undang-Undang yang ada. Oleh sebab itu ASN sebagai profesi yang memiliki kewajiban mengelola dan mengembangkan diri dan wajib mempertanggungjawabkan

kinerjanya dan menerapkan prinsip merit dalam pelaksanaan manajemen Aparatur Sipil Negara.

4. Aparatur Sipil Negara harus memiliki kompetensi diantaranya karena tuntutan tugas pokok, fungsi, kewenangan dan tanggunjawab yang harus dilaksanakan yaitu memberikan pelayanan publik; pelaksanaan keperintahan yang baik (good governance); dalam upaya mengimbangi perubahan lingkungan strategis yang cepap berubah, baik itu lingkungan internal organisasi, maupun lingkungan eksternal organisasi; perkembangan ilmu pengetahuan, teknologi dan era globalisasi yang sedang berlangsung yang tidak bisa ditolak dan dicegah lagi; serta pelaksanaan otonomi daerah. Dengan memahami tanggungjawab, Hak dan kewajiban ASN, menciptakan kondisi Pelayanan ASN terhadap masyarakat lebih baik.

\section{Saran}

1. Pembinaan terhadap ASN agar terus dilakukan sehingga ASN tetap mampu memberikan 
pelayanan yang maksimal kepada masyarakat.

2. Setiap ASN harus mampu menjadi teladan bagi Pegawai lainnya dalam bersikap, berlaku dan dalam bekerja.

3. Setiap ASN wajib menjalankan tugas dengan sebaikbaiknya penuh rasa tanggungjawab kepada masyarakat, bangsa dan negara.

4. Peningkatan terhadap kesejahteraan ASN terus dilakukan oleh Pemerintah agar tercipta ASN yang sejahtera.

5. Sanksi tegas bagi ASN yang tidak menjalankan tugas dengan baik, tidak memahami tanggungjawab dan hak serta kewajibannya sebagai Pegawai Pemerintah.

6. Sanksi tegas bagi ASN yang melakukan pelanggaran yang sesuai birokrasi yang ada dalam setiap Lingkup Lembaga/Instansi yang dijalankannya.

7. Perlu diberikan penghargaan bagi ASN yang menjalankan tugas dengan baik.

\section{Daftar Pustaka}

Buku-buku :

Albrow, Martin, 2007, Birokrasi, diterjemahkan M.Rusli Karim dan Totok Daryanto, Tiara Wacana, Yogyakarta.

Assidiqqie, Jimly, 2005, Format Kelembagaan Negara dan Pergeseran Kekuasaan dalam UUD 1945, F.H.UII Press, Yogyakarta.
2006, Sengketa

Kewenangan Konstitusional
Lembaga Negara, Konstitusi Press \& Syaamil Cipta Media, Jakarta.

Basah, Syahran, 1977, Eksistensi dan Tolok Ukur Badan Peradilan Administrasi Negara Di Indonesia, Bandung: Penerbit : Alumni.

Bambang Rudito, dkk, 2016, Aparatur Sipil Negara Pendukung Reformasi Birokrasi, Jakarta: Penerbit Kencana.

Busroh, Abu Daud, 1985, Asas-asas Hukum Tata Negara, Jakarta: Penerbit : Ghalia Indonesia.

Dwiyanto, Agus, 2008. Mewujudkan Good Governance Melalui Pelayanan Publik, Yogyakarta, Gadjah Mada University Press.

Mutiarin, D., \& Zaivudin,A.(2014). Manajemen Birokrasi dan Kebijakan. Yogyakarta: Pustaka Pelajar.

Wibowo, 2012, Manajemen Perubahan (3rded.).Jakarta; Rajawali Pers.

Peraturan Perundang-undangan:

UUD Tahun 1945

UU No. 5 Tahun 2014 Tentang Aparatur Sipil Negara 